\title{
Reports
}

\section{A NEW BATHYMETRIC MAP OF THE MIDDLE LAURENTIAN FAN}

DAVID C. EDGAR and DAVID J.W. PIPER

Departments of Geology and Oceanography, Dalhousie University, Halifax, Nova Scotia

\section{INTRODUCTION}

The Laurentian Fan seaward of the Laurentian Channel between Nova Scotia and Newfoundland is the largest sediment body on the outer part of the continental margin off Nova Scotia (Parsons 1975). Near-surface Quaternary sediment on the middle fan shows evidence (in sedimentary structures and facies distribution) of deposition from turbidity currents (Stow 1975, Piper 1975). On the upper fan, seismic reflection profiles show slumping is very widespread. A slump triggered by the 1929 Grand Banks earthquake appears to have generated a major turbidity current which transported sediment far out into the Sohm Abyssal Plain (Heezen and Ewing 1952, Heezen and Drake 1964, Fruth 1965).
A new map (Fig. 1) has been compiled of the section of the fan between $42^{\circ} \mathrm{N}$ and $43^{\circ} 30^{\prime} \mathrm{N}$, mostly using data collected from C.S.S. HUDSON in the past five years. Our map is substantially different from the interpretation of the Canadian Hydrographic Service (1970)

\section{NAVIGATION AND COMPILATION PROCEDURES}

All the C.S.S. HUDSON lines are positioned by the aid of satellite navigation and Loran-C, using the east coast chain. The Loran-C provides continuous position data: the satellite navigation is used to check whether the Loran- $C$ is locked into the correct signal peak, or whether there is a systematic error in position. Crossover checks

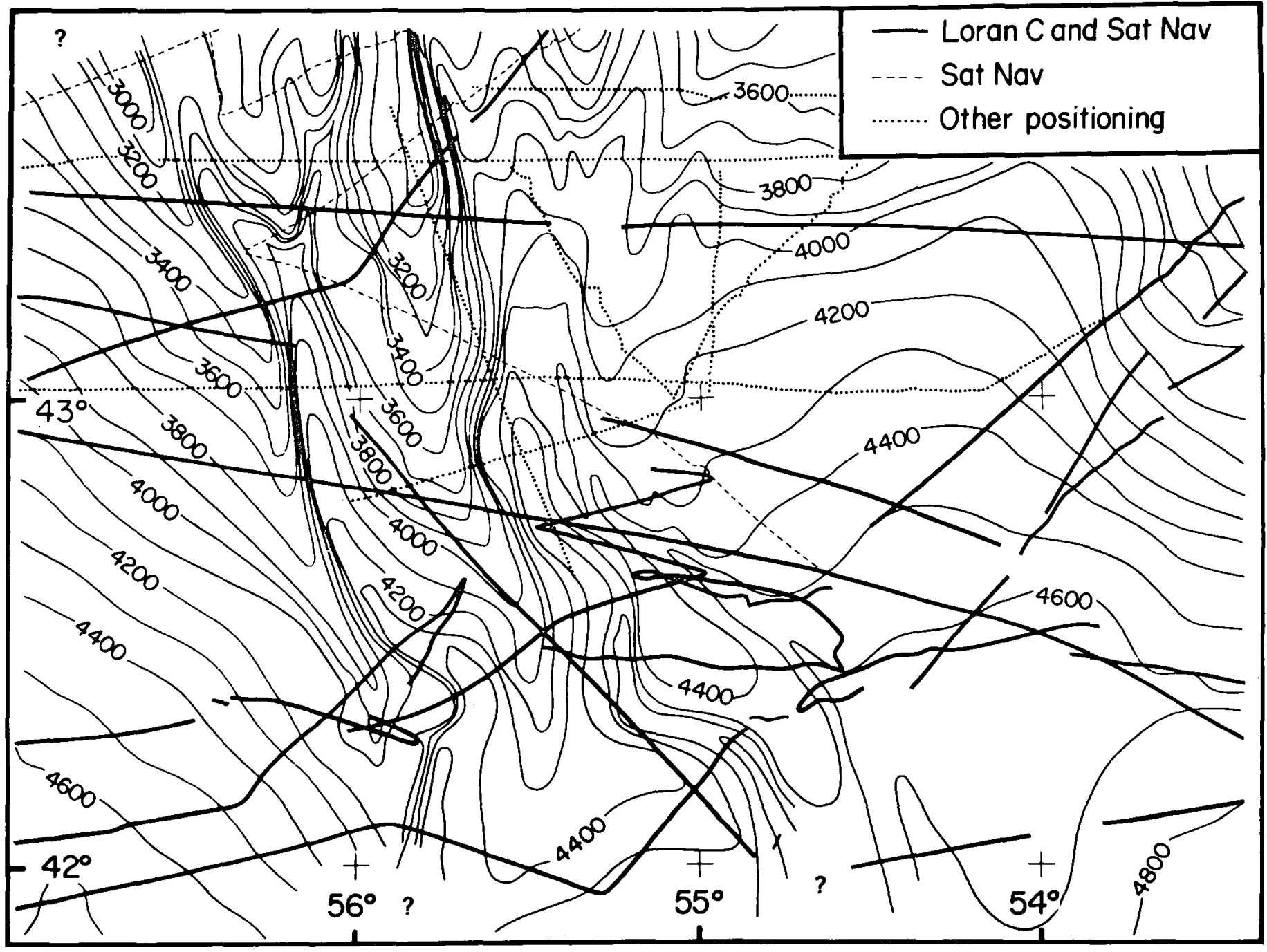

Fig. 1 Bathymetric map of the middle Laurentian Fan, showing ships' tracks on which bathymetry is based. Contours in uncorrected metres, $v=1469 \mathrm{~m} / \mathrm{sec}$. 
with existing bathymetric data can also be used to detect systematic errors in Loran-c. The accuracy of the Loran-C, once locked in correctly to the signal, appears to be about $\pm 1 \mu$ secs on the signal, which corresponds in the area of the middle Laurentian Fan to $\pm 200 \mathrm{~m}$ in an east-west direction and $\pm 800 \mathrm{~m}$ in a north-south direction. The bathymetric depths at crossovers of all our well navigated lines coincide within the limits of accuracy of the Loran-C navigation.

Farlier poorly navigated lines (using Loran A and dead reckoning) have been used only to fill in bathymetric trends in areas for which good data are not available.

The data has been contoured at $200-\mathrm{m}$ interyals. Depths are in uncorrected metres, assuming a velocity of $1469 \mathrm{~m} / \mathrm{s}$. The principal assumption in contouring was that prominent channels were continuous and got deeper to the south. All our data support this assumption.

\section{INTERPRETATION}

The lower Laurentian Fan projects 80 to $100 \mathrm{~km}$ south of the general line of the continental rise off Nova Scotia and Newfoundland. The projecting mass is cut by three major submarine channels, here referred to as the eastern, central and western valleys.

At about $43^{\circ} 20^{\prime} \mathrm{N}$, a number of tributary valleys merge to form the three main valleys. These tributaries drain the irregular, slumped topography of the upper fan (Canadian Hydrographic Service 1970). The upper parts of the western and central valleys, and probably all of the eastern valley are straight. There are prominent meanders on the lower parts of the western and central valleys. The junction with the Sohm Abyssal Plain is around $41^{\circ}$.

The valleys are apparently flanked by levees, those of the western and central valleys being most pronounced. The levees are depositional features and not eroded slump blocks. This is shown by the gradual thickening of sediment towards the channels seen in seismic reflection profiles (Emery et al 1970, Fig. 18, especially the most westerly levee), the similar gradients of the levee crests and valley floors, and changes in levee height around meanders.

The channel-levee system is very asymmetric. The western levees are higher than the eastern ones, and the western valley sides are also much steeper. The difference in height is difficult to quantify rigorously, because the eastern levee of one channel merges with the western levee of the next, but in areas where such interference is minimal, the height difference ranges from $150 \mathrm{~m}$ to $600 \mathrm{~m}$. Some valley asymmetry is common in north-south oriented turbidity current channels, and is believed due to the Coriolis force deflecting the turbidity current to the right (Menard 1955). However, it is rarely so pronounced as on the Laurentian Fan. Compare, for example, Cascadia Channel (Griggs and Kulm 1970) at the same latitude in the eastern Pacific. A second process leading to the same result on the Laurentian Fan is transport of the fine "tail" or upper overbank portion of a turbidity current westwards by the Western Boundary Current (Emergy and Uchupi 1972, p. 229), before the sediment has time to be deposited. Evidence of this process is the red sediment with Carboniferous palynomorphs derived from the Gulf of St. Lawrence and found off Florida (Needham, Habib and Heezen 1969). The asymetric levees suggest that large amounts of suspended sediment are transported a short distance (a few $\mathrm{km}$ ) from the channel, but that the proportion transported drops off sharply moving further from the channel.

Levee heights and the projection of the fan south into the abyssal plain both indicate that the eastern channel has transported and deposited substantially less sediment than the other two. There are at present insufficient data at latitude $43^{\circ} 10^{\prime} \mathrm{N}$, but it appears that the eastern channel and the central channel may be distributaries from a single major channel. The coriolis force would tend to deflect a turbidity current westwards into the central channel. The western tributaries of this combined channel drain from the Laurentian Channel; the eastern tributaries from Halibut Channel (Canadian Hydrographic Service 1970). The eastern tributaries thus probably supplies far less sediment, because most of the sediment is ultimately derived from glacier ice in the Laurentian Channel.

The channel patterns are similar to those found by Curray and Moore (1971) on the Bengal Cone, in contrast to the sandier fans described by Normark (1970). Abundant tributary valleys at depths up to $3000 \mathrm{~m}$, occasional bifurcation of channels, prominent levees, and only a poorly developed suprafan appear to characterize deep sea fans with turbidity currents generated by the slumping of muddy sediments.

\section{ACKNOWLEDGEMENTS}

We thank C.E. Keen, C.M. Boyd and F. Aumento, chief scientists of Bedford Institute of Oceanography cruises 72-021, 73-011, 73-031 and 74-003, and the Master, officers and crew of C.S.S. HUDSON. The Data Processing group at the Atlantic Geoscience Centre (BIO), especially K. Shih, L. Johnson and A. Sherin have provided much help, as has $\mathbf{N}$. Stuifbergen of the Navigation Group of BIO. G. Webb kindly supplied us with additional data and A. McCallum assisted with the drafting. This work is supported by the National Research Council of Canada Operating Grant A8390, and an Imperial Oil University Research Grant.

\section{REFERENCES}

CANADIAN HYDROGRAPHIC SERYICE 1970, Bathymetric chart: Newfoundland Shelf No. 802 .

CURRAY, J.R, and MOORE, D.B., 1971, Growth of the Bengal deep-sea fan and denudation in the Himalayas. Geol. Soc. Amer. Bull., 82, pp. 563-572.

EMERY, K.O., UCHUPI, E., PHILLIPS, J.D., BOWIN, C.O., BUNCE, E.T. and KNOTT, S.T. 1970, Continental rise off eastern North America. Amer. Assoc. Petrol. Geol. Bull., 54, pp. 54-108.

EMERY, K.O. and UCHUPI, E., 1972, Western North Atlantic Ocean. Amer. Assoc. Petrol. Geol., Memoir 17, $532 \mathrm{pp}$.

FRUTH, L.S., 1965, The 1929 Grand Banks turbidite 
and the sediments of the Sohm Abyssal Plain.

M.Sc. thesis, Columbia University.

GRIGGS, G.B. and KULM, L.D., 1970, Sedimentation in Cascadia deep-sea channel. Geol. Soc. Amer. Bul1., 81, pp. 136I-1384.

HEEZEN, B.C. and DRAKE, C.I., 1964, Grand Banks Slump. Amer. Assoc. Petrol. Geolog. Bull., 48, pp. 221-225.

HEEZEN, B.C. and EWING, M., 1952, Turbidity currents and submarine slumps and the 1929 Grand Banks earthquake. Amer. J. Sci., 250, pp. 849-873.

MENARD, H.W., 1955, Deep sea channels, topography and sedimentation. Amer. Assoc. Petrol. Geolog. Bull., 39, pp. 236-255.

NEEDHAM, H.D., HABBID, D. and HEEZEN, B.C., 1969, Upper Carboniferous palynomorphs as a tracer of red sediment dispersal patterns in the northwest Atlantic. J. Geol., 77, pp. 113-120.

NORMARK, W.R., 1970, Growth patterns of deep sea fans. Amer. Assoc. Petrol. Geol. Bul1., 54, pp. $2170-2195$

PARSON, M.G., 1975, The Geology of the Laurentian Fan and the Scotia Rise. Can. Soc. Petrol. Geolog., Memoir 4, pp. 155-167.

PJPER, D.J.W., 1975, Late Quaternary deep-water sedimentation off Nova Scotia and western Grand Banks. Can. Soc. Petrol. Geolog., Memoir 4, pp. 195-204.

STOW, D.A.V., 1975, The Laurentian Fan: late Quaternary stratigraphy. Unpubl. report, Department of Geology, Dalhousie University. $82 \mathrm{pp}$. 